\title{
ПІДВИЩЕННЯ ЕФЕКТИВНОСТІ ПУБЛІЧНОГО УПРАВЛІННЯ ЗАСОБАМИ ЕЛЕКТРОННОГО УРЯДУВАННЯ
}

\author{
Ткачук Л. М., Стахова О. А.
}

\section{ВСТУП}

Сучасні глобалізаційні та інтеграційні процеси у світовій економіці підвищують роль і значення публічного управління в умовах децентралізації влади. Розв'язання державних і регіональних проблем соціально-економічного розвитку має базуватися на європейських цінностях, на засадах демократії та національної єдності, орієнтуватися на підвищення економічних і соціальних стандартів життя для всіх громадян країни.

Система публічного управління в Україні переобтяжена політичною та економічною кризами, депресивністю розвитку регіонів, диспропорціями у взаємовідносинах між державою та регіонами, що свідчить про неефективність іiі функціонування та необхідність реформування в контексті євроінтеграційної стратегії.

Стрімкий розвиток сучасних інформаційних технологій спонукав до створення та розбудови інформаційного суспільства, в якому завдяки використанню інформаційно-комунікаційних технологій i широкому доступу до інформаційних ресурсів з'явилася реальна можливість вибудувати ефективну модель взаємовідносин між органами державної влади та місцевого самоврядування з громадянами та бізнесом.

У період розвитку інформаційного суспільства, впровадження цифрових інформаційних технологій публічне управління, його зміст і форма потребують реформування, яке насамперед забезпечується впровадженням електронного урядування. В широкому розумінні електронне урядування - це форма державного управління за допомогою комп'ютерних та інформаційних технологій, що містить систему взаємопов'язаних елементів, де особливе місце посідає дотримання безпеки інформації.

Запровадження електронного урядування в державі $є$ складним процесом, що вимагає значних фінансових витрат і розв'язання цілого комплексу взаємозалежних політичних, правових, адміністративних i технологічних проблем.

Впровадження електронного урядування передбачає реалізацію послідовного, комплексного та індивідуалізованого підходу до надання державних послуг та інформації для населення, що включає структурну 
перебудову функціонування державних органів і їхньої взаємодії 3 громадянами, організаціями та власними співробітниками.

\section{1. Електронне урядування як форма взаємодії влади і суспільства в публічному управлінні}

Проблема ефективності публічного управління пов'язана перш за все 3 поступовим переформатуванням окремого розгляду державного управління, місцевого самоврядування та громадянського суспільства на їх системне бачення в контексті публічного управління ${ }^{1}$. Процес управління - це сукупність неперервних постійних взаємопов'язаних дій і функцій, які спрямовані на забезпечення досягнення конкретних цілей. У публічному управлінні він формується внаслідок взаємодії органів державної влади та органів місцевого самоврядування із суспільством або між собою. Це насамперед процес продукування та реалізації регулювальних, організуючих і контролюючих впливів у всіх сферах і галузях суспільства, що покладений в основу діяльності суб'єктів публічного управління.

Процес публічного управління - це узагальнений розширений інтегрований процес, який насправді формується 3 великої кількості процесів, що деталізуються на циклах управління через конкретизацію певних суб'єктів та об'єктів управління. Отже, дослідження узагальненого процесу дає змогу давати правильну оцінку проблемним ситуаціям щодо становлення й розвитку публічного управління в країні, тому, згідно із закономірністю цілісності системи, в ній виникають інтегративні риси, що не властиві окремим компонентам.

Ефективність процесу публічного управління значною мірою залежить від дієздатності системи державної влади та стану суспільства, рівня та активності суспільної діяльності, оперативності та ефективності реагування на проблемні ситуації в державі.

У стабільних економічних умовах процес публічного управління, як правило, набуває характеру стратегічного, а під час кризового управління він забезпечується в межах чинних законів політичної боротьби обмеженням прав і свобод громадян, а також значним звуженням дії механізмів саморегуляції.

У сучасних умовах електронне урядування розглядається як ефективний інструмент, що застосовується в цивілізованому світі для задоволення щораз більших потреб суспільства ${ }^{2}$.

1 Голобуцький О.П., Шевчук О.Б. Електронний уряд. Київ : Атлант UMS, 2002. 173 c.

2 Азарова А.О., Хомяк В.Д, Стахова О.А., Хошаба О.М. Інформаційне забезпечення електронного врядування. Молодь в науиі: дослідження, проблеми, 
Відповідно, створення ефективної системи публічної адміністрації, що надаватиме якісні публічні послуги суспільству, стало метою адміністративних реформ. Для іiі досягнення почали говорити саме про ідеологію «служіння суспільству» як про фундаментальний принцип функціонування публічної адміністрації. У межах такої ідеології розв'язувалися завдання щодо:

а) створення стабільної та ефективної організації та діяльності виконавчої влади;

б) забезпечення професійної, політично нейтральної та відкритої публічної служби;

в) формування системи спроможного місцевого самоврядування;

г) підвищення статусу громадянина у відносинах 3 органами публічної адміністрації;

г) забезпечення підконтрольності публічної адміністрації політичній владі та суспільству ${ }^{3}$.

Саме тому необхідно виокремити сутнісні особливості електронного урядування як складника публічного адміністрування та публічного управління. Демократизація публічного управління, зокрема введення в електронний уряд електронної демократії, зумовило появу нового терміна - «електронне урядування». Щодо визначення електронного урядування застосовуються різні підходи, кожен з яких розкриває його особливості залежно від сфери застосування. При цьому найбільш вживаними $€$ такі:

- технократичні, в яких електронне урядування розглядається як одна з базових технологій інформаційного суспільства разом із такими технологіями, як електронна комерція, електронні освіта, культура, охорона здоров'я, наука, охорона довкілля тощо або як один з етапів впровадження інформаційних технологій у державне управління (комп'ютеризація - інформатизація - електронне урядування) як відповідної організаційно-технічної системи;

- теоретичні, в яких електронне урядування розглядається як відповідна ідеологія, концепція, теорія або як одна із сучасних форм державного управління, що конкурує або базується на таких підходах, як новий державний менеджмент, політичні мережі, належне урядування (“good governance”), «відкритий уряд», синергетичний i новий інституційний підходи тощо.

перспективи : тези Всеукр. наук.-практ. інтернет-конф. студ., асп. та мол. наук. 2019. URL: https://conferences.vntu.edu.ua/index.php/mn/mn2019/paper/viewFile/8111/ 6757 (дата звернення: 23.05.2020).

3 Публічне управління та адміністрування : навч. посібник / А.О. Азарова, Л.М. Ткачук, Л.О. Нікіфорова та ін. Вінниця : ВНТУ, 2019. 182 с. 
Розглянемо кілька концепцій електронного урядування (е-урядування):

- як форма організації державного управління, що сприяє підвищенню ефективності, відкритості та прозорості діяльності органів державної влади та органів місцевого самоврядування з використанням IКТ для формування нового типу держави, орієнтованої на задоволення потреб громадян ${ }^{4}$;

- оптимізація процесу надання адміністративно-соціальних послуг, політичної участі громадян у державній розбудові шляхом зміни внутрішніх і зовнішніх відносин за допомогою технічних засобів, Інтернету та сучасних засобів масової інформації;

- система взаємодії органів державної влади 3 населенням, що будується на широкому застосуванні інформаційних технологій із метою підвищення доступності та якості державних послуг, зменшення строків їх надання, а також зниження адміністративного навантаження на громадян та організації щодо їх отримання ${ }^{5}$;

- електронне урядування $є$ не лише модернізацією всієї системи державного управління, але й налагодженням активної взаємодії органів державної влади 3 громадянами за допомогою сучасних інформаційно-комунікаційних технологій ${ }^{6}$;

- використання інформаційних і комунікаційних технологій для підвищення ефективності, економічності та прозорості уряду й можливості громадського контролю за ним ${ }^{7}$.

Головним складником електронного урядування $є$ електронний уряд - єдина інфраструктура міжвідомчої автоматизованої інформаційної взаємодії органів державної влади та органів місцевого самоврядування між собою, з громадянами і суб'єктами господарювання ${ }^{8}$.

Сьогодні термін «електронний уряд» (англ. - “e-government”) $€$ набагато ширшим поняттям, ніж просто «використання в органах державного управління сучасних інформаційних технологій 9

${ }^{4}$ Иванов В.В., Коробова А.Н. Государственное и муниципальное управление с использованием информационных технологий. Москва : ИНФРА-М, 2013. С. 24.

${ }^{5}$ Кил Л., Элиот И. Экономические циклы и реформа государственной службы в США. Госуд. служба за рубежом. Реформы госуд. упр. накануне третьего тысячелетия : реферат. бюлл. № 6 (31). Москва : РАГС, 1999. С. 58-59.

6 Модернізація державного сектору: відкритість влади. Policy Brief. 2007. Квітень. С. 1-2.

${ }^{7}$ Нові управлінські цінності. Бюрократ. 2007. № 8-9. С. 7.

${ }^{8}$ Окинавская хартия информационного общества (G8). URL: http://www.iis.ru/ events/okinava/charter.ru.html (дата звернення: 03.05.2020).

${ }^{9}$ Ткачук Л.М., Стахова О.А., Вергеліс В.О., Хошаба О.М. Сучасні підходи до електронного урядування. Молодь в науці: дослідження, проблеми, перспективи : 
E-government у сучасному розумінні охоплює не лише мережеву інфраструктуру виконавчої влади, але загалом усю інфраструктуру органів влади. Свропейська комісія визначила електронний уряд як «використання інформаційних і телекомунікаційних технологій у державних адміністраціях у сукупності з проведенням організаційних змін і набуттям нових навичок, спрямованих на поліпшення суспільних служб i демократичних процесів, а також посилення підтримки державної політики. Електронний уряд $\epsilon$ засобом для підвищення ефективності державного обслуговування. Він спрощує провадження державної політики й допомагає державному сектору, з одного боку, розширювати обсяг послуг і підвищувати їхню якість, а 3 іншого збільшувати економію ресурсів» ${ }^{10}$.

Для забезпечення ефективності електронного врядування в сфері публічного управління необхідно:

- чітко визначити кінцеві цілі, яких необхідно досягти під час впровадження електронного урядування, критерії їх досягнення;

- сформувати концепцію, стратегію та програму розвитку електронного урядування 3 урахуванням технічної та фінансової спроможності держави;

- здійснити нормативно-правове, організаційно-технічне та інформаційно-аналітичне забезпечення електронного урядування;

- забезпечити підготовку та перепідготовку висококваліфікованих кадрів в органах публічного управління;

- реалізувати механізми взаємодії органів державної влади, місцевого самоврядування, бізнесу та громадян.

\section{2. Організація захисту конфіденційної інформації}

\section{та електронного документообігу в публічному управлінні}

Сучасне законодавство України щодо регулювання питання електронного урядування поповнилось низкою нормативно-правових актів, в яких електронне урядування розглядається як складник процесу інформатизації суспільства, спрямований на підвищення ефективності публічного управління. 20 вересня 2017 року Кабінетом Міністрів

тези Всеукр. наук.-практ. інтернет-конф. студентів, аспірантів та молодих науковців. 2019. URL: https://conferences.vntu.edu.ua/index.php/mn/mn2019/paper/ view/8101 (дата звернення: 23.05.2020).

10 Азарова А.О., Костюк Т.С., Стахова О.А., Хошаба О.М. Публічне адміністрування як процес прийняття управлінських рішень. Молодь в науиі: дослідження, проблеми, перспективи : тези Всеукр. наук.-практичної інтернет-конф. студ., асп. та мол. наук. 2019. URL: https://conferences.vntu.edu.ua/index.php/mn/ mn2019/paper/view/ 8116/6760. (дата звернення: 23.05.2020). 
України схвалено нову Концепцію розвитку електронного урядування в Україні ${ }^{11}$, в якій розвиток електронного урядування визначено одним із першочергових пріоритетів реформування системи державного управління. Також у межах реалізації Угоди про асоціацію між Україною та Європейським Союзом Україна має забезпечити комплексний розвиток електронного урядування відповідно до європейських вимог.

Крім того, є низка нормативно-правових актів різного рівня - від законів України до відомчих актів, що опосередковано впливають на електронне урядування: закони України «Про інформацію», «Про концепцію національної програми інформатизації», «Про Національну програму інформатизації», «Про основні засади розбудови інформаційного суспільства в Україні», «Про доступ до публічної інформації», «Про захист персональних даних», «Про адміністративні послуги», «Про захист інформації в інформаційно-телекомунікаційних системах», «Про електронні документи та електронний документообіг», «Про електронний цифровий підпис», «Стратегія розвитку інформаційного суспільства» тощо.

Однак, безперечно, розбудову національної системи електронного урядування можливо забезпечити тільки в межах реформування всієї системи публічної влади. Це потребує модернізації насамперед усієї системи публічного управління та адміністрування, проведення ефективної адміністративної реформи. Саме ж завдання розбудови національної системи електронного урядування в Україні $\epsilon$ масштабним, таким, яке потребує значних витрат часу та ресурсів, оскільки великою проблемою української влади завжди була ії певна безсистемність, невизначеність і нерегламентованість ії взаємовідносин із кінцевими споживачами державно-управлінських послуг.

Зростання обсягів інформації та даних, що зберігаються й опрацьовуються в електронному вигляді в органах державної влади та місцевого самоврядування, потребує посилення захисту конфіденційних даних, покращення методів, заходів і засобів захисту, адже конфіденційна інформація повинна захищатися не тільки від утрати, але й від модифікації та недозволеного виходу такої інформації за межі зони функціонування, що захищається, або встановленого кола осіб, які мають право працювати 3 нею ${ }^{12}$. Відповідальність за

11 Про схвалення Концепції розвитку електронного урядування в Україні ; Кабінет Міністрів України: Розпорядження КМУ від 20 вересня 2017 р. № 649-р. URL: https://www.kmu.gov.ua/npas/250287124 (дата звернення: 02.06.2020).

12 Азарова А.О., Гудзь В.О., Блонський В.О. Управління інформаційною безпекою в державних установах на основі біометричної аутентифікації відбитків пальців для захисту інформації від несанкціонованого доступу. Матеріали XLVIII 
забезпечення правильного обліку, зберігання i використання конфіденційних документів несуть керівники установ, а виконання обов'язків обліку та зберігання покладається на працівників організацій, що становлять потенційну загрозу для оброблюваної інформації. Неможливо досягти надійного захисту інформації тільки організаційними методами, тому важливим $€$ використання сучасних технічних рішень ${ }^{13}$.

Використання біометричної аутентифікації користувачів шляхом зчитування відбитків пальців для надання доступу до інформації надає низку таких переваг:

- стовідсоткова наявність ознак доступу користувача, адже вони невіддільні від людини;

- фіксування часу аутентифікації та користувача з ID;

- відпадає необхідність запам'ятовування паролів, інколи декількох;

- важкість підробки фізіологічних ознак для отримання доступу несанкціонованим користувачем (зловмисником);

- миттєве сповіщення системи охорони про несанкціонований доступ;

- надання кожному користувачеві унікального ідентифікаційного номера.

Інформаційна безпека - найважливіший елемент системи безпеки публічного управління та адміністрування. Заходи із забезпечення інформаційної безпеки, 3 одного боку, спрямовані на охорону конфіденційної інформації (зокрема, усунення «жучків», запобігання несанкціонованому доступу до локальних комп'ютерних мереж тощо); 3 іншого - містять контрзаходи (пошук даних про конкурентів, партнерів і контрагентів), які сприяють розвитку довіри до владних структур із боку суспільства та слугують для запобігання неприємним несподіванкам.

Масштабне протікання процесів публічного управління, пов'язаних із проявом небезпеки та можливістю завдання збитків, виявляється у вигляді інформаційних війн, масштаби яких нині набули величезних розмірів і специфічних форм прояву. Водночас необхідно зазначити, що відкритість суспільства, залучення до розв'язання складних проблем публічного управління великої кількості людей, ресурсів цілих країн супроводжуються низкою негативних явищ, які безпосередньо

науково-технічної конференції підрозділів ВНTУ. Вінниця. 2019. URL: https://conferences.vntu.edu.ua/index.php/all-fm/all-fm-2019/paper/view/7429. (дата звернення 23.05.2020).

${ }^{13}$ Комплексні системи захисту інформації : навчальний посібник / [Яремчук Ю. С., Павловський П. В., Катаєв В. С., Сінюгін В. В.] - Вінниця : ВНТУ, 2017. - 120 с. 
пов'язані з використанням інформації, інформаційних продуктів i послуг зокрема ${ }^{14}$ :

- численні порушення у фінансово-кредитній сфері (шахрайство, обман, неправомірні дії 3 документацією у сфері електронного документообігу, електронного урядування тощо);

- несанкціонований доступ до конфіденційної інформації;

- неправомірні зміни, що спотворюють зміст інформації, внаслідок чого вона втрачає свою юридичну значимість і цінність;

- численні явища, що призводять до значних негативних наслідків у масштабах цілої країни, які сьогодні об'єднуються загальною назвою «інформаційна війна».

Особливої шкідливості набувають загрози у кіберпросторі, оскільки вони $є$ постійно змінюваними. Для органів публічного адміністрування особливої актуальності набуває використання проривних технологій і тенденцій, таких як Інтернет речей, хмарні технології, мобільні пристрої та контроль за ризиками, що виникають у системі електронного урядування ${ }^{15}$.

Державні службовці органів публічної влади усвідомлюють необхідність забезпечення передових технологій кібербезпеки. Незважаючи на інформаційно-пропагандистську роботу, що проводять 3МI, вони $\epsilon$ не досить комп'ютерно грамотними i не завжди сприймають повною мірою такі загрози, не дотримуючись необхідних умов із реалізації заходів культури кібербезпеки.

Розв'язання таких проблем на рівні держави має здійснюватися на основі [14]:

- створення повнофункціональної інформаційної інфраструктури всіх гілок між владою та громадами й забезпечення захисту іiі критичних елементів;

- підвищення рівня координації діяльності державних органів щодо виявлення, оцінювання та прогнозування загроз інформаційній безпеці у процесах публічного управління, запобігання таким загрозам i забезпечення ліквідації їхніх наслідків, врахування міжнародного досвіду з цих питань;

14 Азарова А.О., Ткачук Л.М., Нікіфорова Л.О., Шиян А.А., Хошаба О.М. Публічне управління та адміністрування в контексті захисту його інформаційного простору. Вісник Житомирського державного технічного університету. 2019. № 2 (88). C. 149-155.

${ }^{15}$ Хошаба О.М. Електронне урядування та електронна демократія : навч. посіб. : у 15 ч. / за заг. ред. А.І. Семенченка, В.М. Дрешпака. Частина 13: Захист інформації в системах електронного урядування. Київ : ФОП Москаленко О.М., 2017. 72 с. 
- вдосконалення нормативно-правової бази щодо забезпечення інформаційної безпеки у процесах публічного адміністрування, зокрема захисту інформаційних ресурсів електронного урядування, протидії комп'ютерній злочинності, захисту персональних даних позивачів i дописувачів, а також правоохоронної діяльності в інформаційній сфері;

- розгортання та розвитку Національної системи конфіденційного зв'язку між владою та народом як сучасної захищеної трансмісійної основи, здатної інтегрувати такі територіально розподілені інформаційні системи електронного урядування різних рівнів, в яких обробляється конфіденційна інформація.

Складність i комплексність проблем електронного урядування сприяє залученню до розв'язання проблеми інформаційної безпеки держави, яка має забезпечити наявність:

- законодавчих, нормативно-правових і нормативних актів щодо інформаційної безпеки;

- відповідність їх міжнародним стандартам ISO;

- власних розробок у напрямі безпечного електронного урядування.

Отже, для реалізації законодавчих, нормативно-правових i нормативних актів щодо інформаційної безпеки електронного урядування має бути створено відповідну потужну систему захисту інформації.

Аналіз наявної системи захисту дав змогу виявити такі державні органи інформаційної безпеки:

- відповідні підрозділи спецслужб держави;

- спеціально уповноважений орган держави 3 питань захисту інформації: Державну службу спеціального зв'язку та захисту інформації України;

- Національний координаційний центр кібербезпеки;

- Міжвідомчу комісію 3 питань інформаційної політики та інформаційної безпеки при Раді національної безпеки і оборони України;

- Державний центр кіберзахисту та протидії кіберзагрозам.

Специфічними службами створення інформаційної безпеки електронного урядування $\epsilon^{16}$ :

- Державна агенція з питань електронного урядування України;

- Державна служба спеціального зв'язку та захисту інформації України;

${ }^{16}$ Азарова А. О., Роїк О. М., Года К. О. Електронний цифровий підпис як засіб захисту інформації на вітчизняних підприємствах. «Економічний простір». № 60. Дніпропетровськ : ПДАБА, 2012. С. 258-263. 
- підрозділ 3 інформаційного забезпечення органу публічного управління, який серед інших завдань також має займатися створенням i підтриманням систем управління інформаційною безпекою та використовує комплексну систему захисту інформації в таких процесах;

- Міністерство юстиції України (у частині роботи з електронними цифровими підписами (ЕЦП)).

Одним із ефективних засобів електронного урядування $\epsilon$ цифровий підпис, серед завдань якого є:

- створення безпеки електронного документообігу;

- убезпечення електронних платіжних систем та електронної комерції;

- забезпечення авторства під час електронного голосування;

- підписування повідомлень електронної пошти;

- аутентифікація (процедура встановлення належності користувачеві інформації в системі пред'явленого ним ідентифікатора) в бездротових мережах;

- створення безпеки мобільної комерції;

- безпечність стільникового зв'язку;

- підписування цифрових сертифікатів і цифрових паспортів на базі смарт-карток.

Потрібно зазначити, що Стратегія кібербезпеки України стверджує необхідність створення умов до залучення господарських суб'єктів різних рівнів, установ та організацій незалежно від форми власності до провадження ними захищеної діяльності у сфері е-урядування. Особливо це стосується захисту інформації розпорядниками об'єктів критичної інфраструктури щодо створення кібербезпеки України. Крім того, ними має розв'язуватися питання щодо обов'язковості застосування заходів із дотримання інформаційної безпеки згідно 3 вимогами чинного законодавства, а також щодо сприяння ними державним органам у виконанні завдань із забезпечення кібербезпеки.

Найбільш ефективним рівнем протидії загрозам i створення інформаційної безпеки є саме законодавчий. Розроблення та впровадження відповідних законодавчих актів створює умови для безпечного використання сучасних інформаційних технологій, захищеного доступу до інформації, захисту іiі від несанкціонованого доступу та витоку технічними каналами. Крім того, важливим питанням для державотворення є захист громадян, суспільства і владних структур від неправдивої інформації, реалізації всіх складників інформаційної безпеки ${ }^{17}$.

${ }^{17}$ Азарова А.О., Хісматулліна В.Ф. Електронні засоби політики інформаційної безпеки на державних підприємствах : мат-ли XLVIII наук.-техн. конф. підрозділів 176 
Національна програма інформатизації формується, спираючись на довгострокові пріоритети соціально-економічного, науково-технічного, національно-культурного розвитку країни 3 урахуванням світових напрямів розвитку та досягнень у сфері інформатизації, i спрямована на розв'язання найважливіших загальносуспільних проблем: державного управління та адміністрування, забезпечення розвитку освіти, науки, культури, охорони довкілля та здоров'я людини, національної безпеки, оборони держави і демократизації суспільства та створення умов для інтеграції України у світовий інформаційний простір відповідно до сучасних тенденцій інформаційної геополітики.

Процеси інтеграції України до світового інформаційного простору викликають особливу потребу в опрацюванні нових підходів до захисту інформації в процесах е-управління.

Урахування закордонного досвіду розбудови системи захищеного еурядування $є$ важливим для України. Практика впровадження систем електронного урядування в різних країнах світу існує понад два десятиліття. За цей час накопичено достатній досвід. Раціональне застосування цих узагальнених результатів дає змогу суттєво економити ресурси, скоротити кількість помилок, розв'язати проблеми стандартизації, уніфікації та взаємодії національної системи електронного урядування 3 міжнародними ${ }^{18}$.

У багатьох країнах, які послуговуються європейськими стандартами до захисту інформації в галузі е-урядування, є такі вимоги:

- захист і конфіденційність інформації в системі електронного урядування;

- фінансовий контроль і пов'язана з ними система внутрішнього управління, включно з фінансовою звітністю;

- державні та місцеві постанови про секретну інформацію (наприклад, про службові таємниці);

- збереження та оброблення інформації третіми сторонами тощо.

Серед загальних проблем, з якими зіткнулися країни $Є С$ під час впровадження електронного урядування, були різні підходи до розв'язання складних ситуацій у напрямі е-урядування. Зокрема, для багатьох країн європейської спільноти домінантною проблемою було забезпечення сумісності різнорідних інформаційних систем публічного

ВНТУ. Вінниця, 2019. URL: https://conferences.vntu.edu.ua/index.php/all-fm/all-fm2019/paper/view/6889. (дата звернення: 23.05.2020).

18 Азарова А. О. Чайковська Я. В. Метод захисту процесів електронного урядування шляхом квантування. Матеріали XLVIII науково-технічної конференції підрозділів ВНТУ. Вінниця. 2019. URL: https://conferences. vntu.edu.ua/index.php/allfm/all-fm2019/paper/ view/79 46. (дата звернення 23.05.2020). 
адміністрування, що створювалися у різні часи, на основі різних принципів і технологічних платформ.

Виникнення таких проблем значною мірою пов'язані із складністю та різнорідністю програмного й апаратного забезпечення, що застосовується в системах електронного урядування, а також зовнішнім доступом до системи е-урядування, оскільки під'єднання зовнішніх користувачів до відкритих сервісів i надання прав державним службовцям органу публічного управління щодо віддаленої роботи 3 внутрішніми інформаційними ресурсами призводить до збільшення загальної кількості небезпек, що постійно з'являються в корпоративній мережі.

Отже, складність і різнорідність програмного й апаратного забезпечення, що використовують у процесах публічного - як вітчизняного, так і закордонного - адміністрування; наявність у системах е-урядування складної розгалуженості вузлів комутації широких мас позивачів і зовнішнього доступу до таких систем, як і складнощі у функціональному поділі обов'язків різних груп обслуговуючого їх персоналу, зумовлюють нагальну потребу у розробленні на теренах українського інформаційного простору уніфікованої системи публічного адміністрування, впорядкованої за загальними принципами європейських стандартів.

Визначення протидії загрозам безпеки в інформаційних системах становить комплексну проблему, для вирішення якої необхідно поєднання заходів на законодавчому, адміністративному, процедурному і програмно-технічному рівнях інформаційної безпеки.

Упровадження нормативно-правових актів у напрямі безпечного публічного адміністрування уможливить захищене використання інформаційно-комунікаційних технологій, доступ до інформації, іiі захист від несанкціонованого доступу та витоку технічними каналами.

На адміністративному рівні захисту інформації в системі публічного управління вирішується визначення керівних документів і стандартів, підходів до управління ризиками та сертифікація на відповідність стандартам інформаційної безпеки.

Іншим рівнем для забезпечення захисту у процесах е-урядування $\epsilon$ процедурний, що регламентує відповідні організаційні заходи. Важливим аспектом процедурного та програмного рівнів протидії загрозам інформаційної безпеки в таких процесах $€$ формування політики безпеки, яка в організаціях, залучених до систем е-урядування, $є$ сукупністю принципів, правил, процедур і практичних рішень у галузі інформаційної безпеки, що регулюють керування, захист і розподіл захищуваної інформації. Першими законами, що прийнято в Україні щодо електронного документообігу, були «Про 
електронний документ та електронний документообіг» (2003 р.) і «Про електронний цифровий підпис» (2003р.). Ці закони визначили: поняття електронного документа, електронного цифрового підпису, сертифікатів ключів цифрового підпису, загальні засади функціонування центрів сертифікації ключів, принципи організації електронного документообігу.

Статтею 5 Закону України «Про електронні документи та електронний документообіг» визначено поняття електронного документа - це документ, інформація в якому зафіксована у вигляді електронних даних, включно з обов'язковими реквізитами документа.

Оригіналом електронного документа $\epsilon$ електронний примірник документа 3 обов'язковими реквізитами, зокрема 3 електронним підписом автора або підписом, прирівняним до власноручного підпису відповідно до Закону України «Про електронний цифровий підпис». Якщо електронний документ надсилається кільком адресатам, то кожен 3 його примірників вважається оригіналом електронного документа. Оригінал електронного документа має довести його цілісність i справжність у порядку, визначеному законодавством.

Юридична сила електронного документа не може бути заперечена виключно через те, що він має електронну форму.

Типовий порядок здійснення електронного документообігу встановлює загальні правила документування управлінської діяльності в електронній формі і регламентує виконання дій 3 електронними документами $з$ моменту їх створення або отримання до відправлення чи передавання до архіву.

Інструмент, що забезпечує легітимність безпаперових технологій документообігу, - це електронний цифровий підпис. Створення електронного документа завершується накладанням електронного підпису.

Основним документом, який регламентує застосування електронного цифрового підпису, є Закон України «Про електронний цифровий підпис».

У правовому аспекті електронний цифровий підпис - це різновид електронного підпису, який за юридичним статусом прирівнюється до власноручного в разі виконання технічних умов, визначених законом. А фізично він являє собою унікальний електронний код, за допомогою якого підтверджується цілісність та юридична сила електронного документа, а також однозначно ідентифікується особа, яка його підписала. Тобто електронний цифровий підпис підтверджує незмінність редакції документа, а у разі внесення до документа навіть найнезначніших коригувань засвідчує, що цей документ уже не має юридичної сили. 


\section{ВИСНОВКИ}

У сучасних умовах електронне урядування розглядається як форма публічного управління, що сприяе підвищенню ефективності, відкритості та прозорості діяльності органів державної влади та органів місцевого самоврядування 3 використанням інформаційно-телекомунікаційних технологій для формування нового типу держави, орієнтованої на задоволення потреб громадян.

Ефективність процесу публічного адміністрування значною мірою залежить від дієздатності системи державної влади та стану суспільства, рівня й активності суспільної діяльності, оперативності й ефективності реагування на проблемні ситуації в державі.

В Україні $\epsilon$ проблеми, пов'язані 3 інформаційним забезпеченням публічного управління. Для їх усунення необхідно:

- вдосконалити нормативно-правову базу електронного урядування;

- розширити та модернізувати наявну інфраструктуру органів публічного управління;

- впровадити систему захисту інформації в органах публічного управління;

- розширити сегмент користувачів сучасними інформаційними технологіями.

На основі проведеного аналізу інформаційних ресурсів органів влади можна констатувати, що Україна у своєму розвитку істотно відстає від розвинених країн і перебуває на початковому етапі впровадження електронного урядування.

Отже, необхідність у розробленні та реалізації проєкту впровадження технології електронного урядування зумовлена низкою факторів, основними з яких $є$ такі:

1) комплексний характер проблем у сфері електронного урядування, які не можуть бути вирішені на рівні окремих органів влади та регіонів, а також на основі традиційних підходів;

2) необхідність об'єднання елементів електронного урядування, створених в окремих органах влади та регіонах України, в єдину систему електронного урядування та формування на їхній основі типових рішень у цій сфері;

3) необхідність зменшення ризику отримання негативних результатів.

\footnotetext{
АНОТАЦІЯ

Статтю присвячено розв'язанню проблеми підвищення ефективності публічного управління в умовах інформатизації суспільства. В роботі розглядаються основні сучасні підходи до публічного управління засобами електронного урядування. Розглянуто 
структуру публічного управління, методи електронного урядування, складники його інформаційно-технологічної інфраструктури, державну політику з розвитку електронного урядування, його технічні складники та їхне призначення. Досліджено механізми взаємодії органів державної влади, місцевого самоврядування, бізнесу та громадян у системі електронного урядування та надання управлінських послуг. Проаналізовано особливості нормативно-правового регулювання електронного урядування в Україні. Обгрунтовано необхідність захисту конфіденційних даних, покращення методів, заходів і засобів захисту інформації не лише від втрати, але й від модифікації та недозволеного виходу за межі зони функціонування або встановленого кола осіб, які мають право працювати 3 нею. Проаналізовано особливості ведення електронного документообігу та застосування електронного цифрового підпису в органах публічного управління.

\section{ЛІТЕРАТУРА}

1. Голобуцький О.П., Шевчук О.Б. Електронний уряд. Київ : Атлант UMS, 2002. 173 c.

2. Азарова А.О., Хомяк В.Д, Стахова О.А., Хошаба О.М. Інформаційне забезпечення електронного врядування. Молодь в науиі: дослідження, проблеми, перспективи : тези Всеукр. наук.-практ. інтернетконф. студ., асп. та мол. наук. 2019. URL: https://conferences.vntu.edu.ua/ index.php/mn/mn2019/paper/viewFile/8111/6757 (дата звернення: 23.05.2020).

3. Публічне управління та адміністрування : навч. посібник / А.О. Азарова, Л.М. Ткачук, Л.О. Нікіфорова та ін. Вінниця : ВНТУ, 2019. $182 \mathrm{c}$.

4. Иванов В.В., Коробова А.Н. Государственное и муниципальное управление с использованием информационных технологий. Москва : ИНФРА-М, 2013. С. 24.

5. Кил Л., Элиот И. Экономические циклы и реформа государственной службы в США. Госуд. служба за рубежом. Реформы госуд. упр. накануне третьего тысячелетия : реферат. бюлл. № 6 (31). Москва : РАГС, 1999. С. 58-59.

6. Модернізація державного сектору: відкритість влади. Policy Brief. 2007. Квітень. С. 1-2.

7. Нові управлінські цінності. Бюрократ. 2007. № 8-9. С. 7.

8. Окинавская хартия информационного общества (G8). URL: http://www.iis.ru/events/okinava/charter.ru.html (дата звернення 03.05.2020).

9. Ткачук Л.М., Стахова О.А., Вергеліс В.О., Хошаба О.М. Сучасні підходи до електронного урядування. Молодь в науці: дослідження, 
проблеми, перспективи : тези Всеукр. наук.-практ. інтернет-конф. студ., асп. та мол. наук. 2019. URL: https://conferences.vntu.edu.ua/index.php/ $\mathrm{mn} / \mathrm{mn} 2019 /$ paper/view/8101 (дата звернення: 23.05.2020).

10. Азарова А.О., Костюк Т.С., Стахова О.А., Хошаба О.М. Публічне адміністрування як процес прийняття управлінських рішень. Молодь в науиі: дослідження, проблеми, перспективи : тези Всеукр. наук.-практ. інтернет-конф. студ., асп. та мол. наук. 2019. URL: https://conferences.vntu.edu.ua/index.php/mn/mn2019/paper/view/811 6/6760. (дата звернення: 23.05.2020).

11. Про схвалення Концепції розвитку електронного урядування в Україні ; Кабінет Міністрів України : Розпорядження КМУ від 20 вересня 2017 p. № 649-p. URL: https://www.kmu.gov.ua/npas/250287124 (дата звернення: 02.06.2020).

12. Азарова А.О., Гудзь В.О., Блонський В.О. Управління інформаційною безпекою в державних установах на основі біометричної аутентифікації відбитків пальців для захисту інформації від несанкціонованого доступу : мат-ли XLVIII наук.-техн. конф. підрозділів ВНТУ. Вінниця, 2019. URL: https://conferences.vntu.edu.ua/ index.php/allfm/all-fm-2019/paper/view/7429 (дата звернення: 23.05.2020).

13. Комплексні системи захисту інформації : навч. посібник / Яремчук Ю.С., Павловський П.В., Катаєв В.С., Сінюгін В.В. Вінниця : ВНТУ, 2017. $120 \mathrm{c}$.

14. Азарова А.О., Ткачук Л.М., Нікіфорова Л.О., Шиян А.А., Хошаба О.М. Публічне управління та адміністрування в контексті захисту його інформаційного простору. Вісник Житомирського державного технічного університету. 2019. № 2 (88). С. 149-155.

15. Хошаба О.М. Електронне урядування та електронна демократія : навч. посіб.: у 15 ч. / за заг. ред. А.І. Семенченка, В.М. Дрешпака. Частина 13: Захист інформації в системах електронного урядування. Київ : ФОП Москаленко О.М., 2017. 72 с.

16. Азарова А.О., Роїк О.М., Года К.О. Електронний цифровий підпис як засіб захисту інформації на вітчизняних підприємствах. «Економічний простір». № 60. Дніпропетровськ : ПДАБА, 2012. C. $258-263$.

17. Азарова А.О., Хісматулліна В.Ф. Електронні засоби політики інформаційної безпеки на державних підприємствах : мат-ли XLVIII наук.-техн. конф. підрозділів ВНTУ. Вінниця, 2019. URL: https://conferences.vntu.edu.ua/index.php/all-fm/all-fm2019/paper/view/6889 (дата звернення: 23.05.2020).

18. Азарова А.О. Чайковська Я.В. Метод захисту процесів електронного урядування шляхом квантування : мат-ли XLVIII 
наук.-техн. конф. підрозділів ВНTУ. Вінниця, 2019. URL: https://conferences.vntu.edu.ua/index.php/all-fm/all-fm2019/paper/view/ 7946 (дата звернення: 23.05.2020).

Information about authors: Tkachuk L. M., Candidate of Science in Economics, Associate Professor of the Department of Finance and Innovative Management of the Vinnytsia National Technical University 95, Khmelnytsky highway, Vinnytsa, 21029, Ukraine

Stakhova O. A., Candidate of Sciences in Pedagogic, Senior Lecturer at the Department of Management and Administration of the Vinnytsia Academy of Continuing Education 13, Hrushevskoho str., Vinnytsa, 21000, Ukraine 